TP Periodica Polytechnica

Social and Management Sciences

22(1), pp. 37-45, 2014

DOI:10.3311/PPSO.7427

http://www.pp.bme.hu/so/article/view/7427

Creative Commons Attribution (i)

RESEARCH ARTICLE

\section{Is It the Crisis to Blame?}

Eszter Solt

RECEIVEd 24 August 2012; ACCepted After REVISIONS 07 November 2013

\section{Abstract}

The aim of this paper is to examine the European Monetary System (EMS) and its Exchange Rate Mechanism (ERM) regarded as the forerunner to European Monetary Union (EMU). It may contribute to understanding the nature and the operation of the monetary integration of the single currency area. The paper examines the reasons why the European Monetary System was formed in 1979, whether its crisis could have been avoided in the early 1990s and how the „new” ERM worked out. The ERM was succeeded by ERM 2 from 1999 in which the euro became the anchor for the other participating currencies. The global economic and financial crisis has brought both the structural and the operational weaknesses of EMU to the surface. The future of the European monetary integration is vital for Europe. The euro crisis is often perceived to have been caused by the global crisis. The ERM did not seem to have laid the groundwork for the monetary union and the Maastricht Treaty also has some critical points determining the operation of EMU in the long run. It is essential to gauge the euro-zone from the aspect of its vulnerability and susceptibility to crises to prevent a recurrence.

\section{Keywords}

monetary integration ' single currency area ' structural system flaws · political union · automatic insurance mechanism - fiscal federalism

Eszter Solt dr. univ Associate Professor

Dennis Gabor College

Mérnök u. 39., H-1119 Budapest, Hungary

e-mail: solt@gdf.hu

\section{Introduction}

The global economic and financial crisis has brought to the surface both the structural and the operational weaknesses of the concept of the monetary union. Documenting the "defects from birth" starts with examining the monetary system in Europe in the late 1970s.

The European Monetary System (EMS) was created in 1979 by eight of the European Union [European Economic Community (EEC) at that time] member states as a prelude to monetary unification. Therefore it is essential to know the economic environment in which it functioned, the way it operated. The roots of the current monetary integration go back to that time and to that system. Revealing its defects may bring us closer to having a bit more understanding of the euroland, and forming views of the monetary environment Europeans can expect to be surrounded by in the forthcoming period of time. Lessons are never late to learn. It is another question when and how the lessons can serve. To put it differently, given the only way what is still to be adjusted: the participants or the surroundings? Or does restricting the rules enable the way to remain? Additionally when it comes to choosing the tool it will prove again that one tool can be good for only one purpose meaning that an economic policy can pursue one goal. In its first eight years the Exchange Rate Mechanism of the EMS, the ERM, was characterized by realignments negotiated by all members in advance thus unilateral devaluations were excluded. Realignments were necessary to correct for differences in inflation rates. Meanwhile capital controls were retained meaning free flow of capital had not been adopted yet, which defended the countries with weak currencies from the downward pressure on their exchange rates and worked as an instrument for them. The period between January 1987 and mid-1992 witnessed no realignments and the ERM had evolved into a de facto fixed-rate system by the late 1980s. Giving up the instrument of limited international capital flows with the exchange rates de facto fixed led to tensions within the system since it meant giving up either the domestic objectives in the member countries (the low inflation) or stable exchange rates. This is what is meant by one economic policy one goal. 
Other issues like the German unification and high German inflation and interest rates following it would also made other member countries to pursue economic policies which does not serve their domestic goals just to keep their exchange rate parities. For the ERM this situation called for transiting into a monetary union with compatible national policies and a single currency. Signing the Maastricht Treaty in 1992 suggested no occurrence of devaluations in the short period of time before the move to a single currency was scheduled in 1999. Investors could capitalize on yield differentials and enjoy safety of facing no exchange rate risk at the same time. The tensions were strengthened by the speculators and the crisis of the ERM emerged in 1992 and later in 1993 again indicating its vulnerability. Despite the Treaty showed optimism it was viewed with skepticism in some countries, the doubts about its acceptance reflected lack of support by the general public. I acknowledge the benefit of hindsight yet the lessons deserve consideration. This paper will argue that underlying structural flaws of the monetary system preceding monetary union, ignorance of early warning signs and the implications of its crisis for the viability of the three-stage Maastricht process have a great impact on the viability of the Monetary Union. It is true that the situation in 1992 was exceptionally unstable coinciding circumstances (German reunification and high interest rates, recession in Europe, uncertainties around the referendum about the Maastricht Treaty in Denmark and in France) were easier to blame for the crisis than exploring the underlying structural system flaws or revealing that the goal of the Single Europe and single currency is a highly political endeavour. Instead of an optimistic assessment of the prospects for EMU timely corrections should have been made. When the euro was born, there was a great wave of sanguineness in Europe. The flood of money that was poured to Spain and other countries regarded as safe investments fostered housing bubbles and trade deficits. The global financial crisis put an end to the flood leaving swamps behind. The financial crisis turned into a fiscal crisis. Austerity measures were introduced as a response causing a fall in investor confidence and political instability meaning that the policies demanded by the European Central Bank are likely impossible to pursue.

\section{The Path to Monetary Union}

On December 10 1991, the leaders of the European Union countries met at Maastricht Netherlands to propose amendments to the Treaty of Rome putting the EU directly on course to European Economic and Monetary Union. The provisions of the Maastricht Treaty called for a start to stage 2 of the Delors plan on January 11994 and a start to stage 3 on January 11999 the latest. Besides its monetary policy provisions the Treaty includes proposals to harmonize social policy and centralize foreign and defense policy decisions within the EU states. The Maastricht Treaty officially the Treaty on European Union (TEU) was signed on 7 February 1992 and entered into force on 1 November 1993. According to the terms of the Treaty it could come into effect only if all EMS members had approved that. Doubts emerged in 1992 about its acceptance shown by the referendums in Denmark and in France reflecting lack of its popular support. When the Treaty had been successfully ratified by all 12 states the process of EMU could begin with Stage 2 and with the establishment of the European Monetary Institute (EMI) a temporary institution to oversee transition to stage 3 in which the ECU, the nucleus of the EMS, the basket of fixed amounts of EU currencies, and national currencies were to be replaced by the single currency, the euro.

In the following part the different alternative path schemes of attaining EMU are discussed.

As for the strategies, there were two opposing groups representing views on how to achieve Monetary Union. According to the „monetarists” progress in monetary field would be followed by a coordination of economic policies effectively (Tsoulkalis, 1977) while the other group, the ,economists”, believed that harmonization of economic policies had the priority (De Grauwe, 1990). The difference in views generated debates around Maastricht at the beginning of the 90s. As for the timetable of adoption the gradualist approach has a specified schedule with criteria to enter the next stage, the „Hawaiian” approach meant a ,shock -therapy" referring to the way Hawaii became a state of the US in a single step. The latter was supported by some leading economists though it had hardly any feasibility in Europe (Giovannini, 1990). The Delors report (1989) exemplified the „monetarist”, gradualist approach. The convergence approach that set entry conditions, the convergence criteria, for member states to move to stage 3 and the use of the ERM to reduce volatility until exchange rates could be fixed before a single currency could be adopted is referred to the Maastricht approach (Artus, 1993). The other possible path to Monetary Union is the „Hard ECU” (Brittan, 2003), the theory of Hayek (1984) on concurrent circulation of currencies put forward in the U.K., according to which the speed of replacement of the national currencies by individuals for the ECU is determined by economic behaviour (Siegel, 1984). This way of transition does not involve an ,end game" meaning a specified time and entry condition. Having shown the different route to EMU, the paper will focus on EMS and its ERM so that it can address the Monetary Union when the problems within the Exchange Rate Mechanism have been examined. The Maastricht approach will be discussed in more detail later in this paper.

\section{Exchange rate stability within the ERM from 1979 to 1987}

Exchange rate stability has particular importance in Europe due to the high reliance of the European economies on international trade illustrated by high degree of their openness, import plus export as a percent of GDP. As a result depreciation or appreciation does much damage to their economies such as 
inflation unemployment or weakening competitiveness. The stability of exchange rates was regarded as a prerequisite to monetary union. The first eight years of the ERM (from 1979 to 1987) were characterized by realignments of exchange rates. Each currency participating in the system had a central rate relative to the ECU, a basket composed of specific quantities of the currencies of European Monetary System members depending on the relative economic weight of the country. According to the terms of the ERM the nominal market exchange rate of each ERM currency was required to be kept vis-à-vis any other ERM currency within 2.25 percent (for the Italian lira 6 percent) bands on each side of the bilateral central parities. These fluctuation margins served as mandatory intervention limits for each central bank, which could stabilize European exchange rates (Giavazzi and Giovannini, 1989). Inflation rate differentials, however, made it necessary for the rates to be realigned. There were 11 realignments in that period (European Economy, 1993). Germany, due to the commitment of the Bundesbank to price stability, which was the predominant goal of German monetary policy, was the centre of the strong currency zone with low inflation. Countries with strong currencies managed to remain in the German mark stability zone and could avoid devaluing their currencies against the German currency. Realignments were necessary for high inflation countries to prevent real exchange rates of weak currencies from increasing and their competitiveness from weakening. This type of a fixed-but-adjustable exchange rate system developed into a de facto fixed-rate system by the early 1990 s as there were no realignments between 1987 and 1992. The inflation rates of the weak currency countries had been lowered by the late 1980s (International Monetary Fund data). The weak currency countries' aversion to devaluation stemmed from the general view that it was regarded as a sign of weak economy and faulty economic policy, which strengthened their central banks' commitment to lowering inflation. Accomplishing the goal of low inflation made devaluation unnecessary. In the ERM practice the German mark had become the ,inflation anchor” of the system. The Bundesbank pursued monetary policies according to the requirements of internal balance, when a conflict emerged - payment surplus, appreciating mark with inflationary pressure - Germany opted for tight money to prevent inflation; the Bundesbank pursued its own preferences. The other ERM countries had to give priority to external balance that is stabilizing their exchange rates and keep balance of payment equilibrium, and use monetary policies, tightening or easing, according to that. The system had all the signs of a currency area anchored to the mark and German monetary policy, which was too tight for the other member states (Mundell, 1994).

\section{The Gains for the Members in the German-Dominated System}

To understand the gains of the EMS two approaches can be used. The interest of the inflation-prone members in the system can be explained by the monetary discipline hypothesis. On the other hand the strategic cooperation is essential in understanding Germany's remaining in the system (Melitz, 1988). They suggest the system benefit all the members. The monetary discipline theory alone does not explain the interest of Germany, while coordinated policies according to game theory do not elucidate German dominance. To put it differently, it was worthwhile for countries with high inflation to join a system in which they could benefit from linking their currencies to that of a country with low inflation. A central bank that has committed itself to a credible strategy of disinflation faces a lower inflation rate and earns reputation in the market place. Within the EMS the countries with relative high inflation such as France and Italy borrowed reputation from low-inflation Germany (Fratianni, 1988). The real exchange rate of high-inflation countries appreciated and realignments returned them to their initial value. An increase in their exchange rates would have impaired the competitiveness of goods produced in the weak currency countries causing a decline in their exports resulting in trade deficits. ERM countries that were able to match the German performance in controlling inflation comprise the strong currency zone of the system. Pegging currencies to the Deutsche mark (DM) was the most important means for importing credibility. The Bundesbank had made price stability the predominant goal of German monetary policy mainly due to the detrimental economic and political consequences of the German hyperinflation of the 1920s. The gains for Germany derived from the integration of European financial markets, which would make Germany less vulnerable to changes in foreign economic policy. With exchange controls relaxed in Italy and France the substitutability between DM denominated assets and those denominated in French franks and in liras increased. Melitz also analysed why Germany wished to stay in the system and demonstrated it by standard applications of game theory. Strategic cooperation did not explain the tightness of monetary policy, but suggested Germany could increase its competitiveness by disinflating between realignments which resulted from keeping nominal exchange rates stable while inflation rates had not fully converged yet. Melitz argues these gains outweighed the costs of German monetary policy, moreover these advantages proved secure and more durable than those of other members pursuing disinflation through the system. Fratianni (1988) also addresses the gains of Germany in the EMS and concludes the system made it possible for the DM to have smaller real appreciations than would have been under free floating. Germany's joining the EMS opposed by the Bundesbank may have been justified by this advantage and it seems to have expressed the intention of the German government to find a scheme against speculative flow as the main motive (Brittan, 1979). The Very Short-term Financing Facility (VSTFF) was available for compulsory intervention in unlimited amounts. The creditor bank had to face exchange risk since claims and liabilities were 
denominated in ECU in the VSTFF. The Bundesbank suffered a loss of over 1 billion DM in its VSTFF to sustain the lira and the pound (Collignon, 1994). The Facility was designed to provide aid for temporary short term balance of payment needs and to defend the exchange rates against speculative attacks when they were to leave the fluctuation margin. The change of rules of intervention and the access automatic credit facilities through VSTFF in 1987 was encouraged by France after its refusing intervention for the franc on the intervention floor, which eventually had to be done by the Bundesbank. The modification of rules was interpreted as the discretion given to Germany to decide in each case. Extension of credit through the Facility was limited by the number of currencies under attack at the same time.

\section{The Evolution of the New ERM}

Since inflation rates in the weak currency members had been lowered to the rates of the strong currency countries, and due to the stigma devaluation meant to one country there were no realignments between January 1987 and 1992. Strong currency was associated with economic strength and prudent national economic policies. The aversion to devaluation relative to the Deutche mark strengthened the central banks' commitment to low inflation and placed the strong domestic currency in the centre of the economic policy. French inflation e.g. was reduced from an average rate of 11 percent to an average of 3.5 percent by this strategy from the early 1980s to the late (Cadot, 1996). The success of this strategy made further devaluations unnecessary. National pride transformed the system from fixed-but-adjustable to a fixed rate system. The Single European Act of 1986 set removal of all remaining trade barriers within the European Community. The Act includes provisions concerning free flow of capital (Council Directive 88/361 EEC, 1988 June 24). The Commission sought to abolish the general arrangements for restrictions on capital movements i.e. all the operations carried out either by a natural or legal person. Capital movement includes direct investments, investment in property, operations in securities, current and deposit accounts, financial loans and credit with effect from July 1, 1990 until December 31 1992. Spain and Ireland were given an extension to 1992, Portugal and Greece to 1995. Capital controls were essential to decrease the downward pressure on the weak currency countries' exchange rates before they were able to lower their inflation rates (Giavazzi and Giovannini, 1989). This policy instrument made it possible for the EMS countries to limit exchange rate volatility and reach a convergence in inflation rates to that of the strong currency members. Capital controls enabled central banks to intervene in currency markets more successfully owing to insulated domestic credit markets from increases in interest rate. Single Europe assumes free mobility of capital. Countries could have allowed it to themselves if they had been protected against the effects of free capital mobility. The success of the EMS during the 1980s was mainly ensured by capital controls supporting the members in achieving their goals of stabilizing the exchange rates and converging inflation rates toward the rate in the strong currency zone. Removing this instrument with fix exchange rates retained meant losing the prospect of achieving the objectives of convergence. Exchange rate stability could be maintained with full convergence. What was created was irreconcilable. If monetary policy aims to achieve domestic goals, the goal of limiting exchange rate fluctuations should be forfeited. The pursuit of one economic goal often restricts obtaining the other. As long as capital controls were maintained, they served as another tool to attain the other goal. Simply put, an economic policy instrument can serve only one goal. Being forced to choose between two economic policy objectives or using one policy instrument and trying to achieve two goals leads to tensions that cannot be maintained even in the short run. In other words it resulted in instability and can be assessed as the system's flaw. Partly due to recognizing the unsustainability of that state, the members put the transformation of the EMS into a full monetary union on agenda according to the recommendation of the Delors Report. The signing of the Maastricht Treaty in 1992 set a timetable for adopting a single currency scheduled January 11999 the latest. It suggested to investors to choose portfolios on the high yield currencies, such as the Italian lira regarding the exchange risk it incurs, without having to be exposed to the risk in fact due to the expectable convergence of economic performance within EMS countries. The timetable set in Maastricht indicated no occurrence of devaluations in the period of moving to the single currency. Such investor moves were termed as „convergence plays”. Bond markets were also affected by convergence phenomenon. In anticipation of monetary union peripheral bond markets (Italian and Spanish) were rising strongly. So were markets in Ireland, Sweden and Finland. If markets believed a country would join EMU, it seemed to be reasonable for the country to align its long-term bond yields with those of Germany- the lowest denominator. The odd trend in capital markets resulted in an impressive narrowing of the premium on Italian and Spanish bonds over those of Germany (Borio and McCauley, 1996). In other words the cost of Italian and Spanish government debt fell, which had little to do with economic fundamentals rather with forcing the monetary union within the set timetable. Technological improvements and new products and services in the financial field facilitated capital flows increasing the degree of international capital mobility (Miller, 1992). Fund flows were based on the belief in convergence of economic policies and performance within the EMS adding a high degree of vulnerability to the new ERM. One direction flows may take a reverse any time if belief is doubted. These dangers were ignored. The doubts emerged in connection with the German reunification and about the ratification of the Maastricht Treaty. 


\section{The Crisis of the New ERM}

German reunification in 1990 caused strains in the EMS. The costs associated with the reunification were financed through borrowing of the German government turning the budget surplus of the previous year to a deficit of $\$ 150$ billion (Clausen and Willms 1994). The large current account surplus in the balance of trade rapidly turned into a deficit as the complement to the import of foreign capital necessary to finance unification. This turn was accompanied by remarkable changes in exchange rates, which made real appreciation of the Deutsche mark necessary against other ERM currencies to furnish the current account deficit. The German government's proposal to realignment was rejected mainly by France with regard of ,franc fort" economic policy of France. To reach the real appreciation of its currency Germany had to have inflation higher than its trading partners. Expansionary fiscal policy and sudden increase in monetary growth following the reunification caused higher inflation, too. The restrictive monetary policy the Bundesbank applied as a response to inflation threat resulted in a massive interest rate increase, from 7.1 percent in 1989 to 9.5 percent in 1992 (Clausen and Willms 1994). Higher German interest rates required other EMS countries to keep interest rates higher than it would have been favourable for them to achieve their domestic macroeconomic objectives. Since the domestic priorities were different in Germany and in the other EMS countries doubts arose in the member states whether it was worth defending the exchange rates by giving up their own goals. Doubts around the ratification of the Maastricht Treaty made the assumption of no devaluation less likely. High inflation countries such as Italy experienced a real exchange rate appreciation and suffered deterioration in their competitiveness producing large current account deficits after the last realignment in 1987. The downward pressure on the lira was strengthened by the reverse of "convergence plays” and speculation on devaluation. The British pound was considered overvalued and became attacked. The strong intervention of the central banks the pound and the lira were forced to be withdrawn from the regime followed by devaluation of the Spanish peseta, the Portuguese escudo and the Irish pound. The new ERM had come to the first stage of the crisis. The second stage began with lowering interest rates in member states due to recession in Europe. As long as it could be done at the same pace as Germany eased its policy the members could avoid weakening their currencies. The priority of the German economic policy was to reduce inflation. The main concern in other EC countries was unemployment. Maintaining fixed exchange rates required single monetary policy. Reducing unemployment is far beyond having only economic implications. Exchange rates had to be abandoned in favour of domestic goals. Despite massive interventions of the central banks the attempt of keeping EMS exchange rates within narrow bands had to be given up. Narrow bands were replaced by a system with 15 percent ranges on each side referred to as de facto floating. Although wide bands were considered temporary no agreement indicated a return to narrow bands or supported its feasibility.

\section{Lack of a Control Mechanism, Lack of an Automatic Insurance Mechanism}

The defects of the system made it less likely for the new ERM to avert the crisis by avoiding mistaken economic policies. Better policies, such as Germany's conducting a less expansionary fiscal policy to reduce the inflationary impacts of reunification, the French government's accepting Germany's proposal for a realignment in 1990 when there was a need for real appreciation of the Deutsche mark to finance unification by the import of foreign capital, flexibility of the other EMS partners in devaluing their currencies when the German proposal arose, Bundesbank's lowering inflation rates to adjust to the domestic goals of the other members, could have been opted for. Correct policies are likely to have impacted the timing or the character or intensity, but unlikely to have altered the outcome significantly since the system was fragile. Mundell compares the EMS to the unanchored dollar system, a dollar standard, set up at the Smithsonian Institution in 1971. It was characterized by the United States' dominance in determining the inflation rate for the whole currency area reflecting its own monetary policy preferences. In that regime the policy of the United States (the inner or center country) lay on its self-discipline with no accountability of convertibility while the other countries (the outer countries) were disciplined by their balance of payments. To put it differently the other countries had no means to make US monetary policy different. The crisis emerged when the inflation preferences conflicted and ended up in the partial breakup of the dollar standard. In the ERM, which had become a mark standard in the 1980s, Germany, the center country, pursued its own monetary policy with its domestic inflation preferences lacking any accountability mechanism while the outer countries were disciplined by the balance of payments under fixed exchange rates and had no influence on German monetary policy. The flaw of both standards was that the monetary policies of the anchor countries were not in line with the goals of the member states of their regimes. The two regimes were different in size. Size is a main determinant of the ability of the center to cushion shocks in the system. Germany, qua anchor, one-third the size of the US economy was one-third as stable. (Mundell, 1994) Both standards lacked the control mechanism that enables partner states to affect the monetary policy of the center thus that of the whole currency area. By contrast the control of the anchored dollar system of Bretton Woods rested on both the partners: on one hand on US monetary policy, on the other hand on gold-dollar portfolio of Europe. The gold-dollar portfolio functioned as the other control variable. In practice European dollar into 
gold moves weakened the US reserve position and forced a monetary contraction whereas gold conversion into dollars strengthened the US reserve position and stimulated or compelled a monetary expansion (Mundell, 1994). The stability of the system was determined by the control mechanism built in it. Control mechanism should work automatically. In the case of the European Monetary Union the analogy lies in the lack of a mechanism working automatically, which would be essential for its stability. Automatic means self-regulating thus the system sustains itself without having to be regulated by making the rules stricter. The subject of the comparison is quite different in the case of Europe since it refers to an automatic insurance mechanism with a centralized budget transferring resources to deficit countries in times of crisis, which could be accomplished only in the frame of a political union (Melitz and Zummer, 1999). The design of the euro-zone rejected any form of automatic insurance mechanism to avoid the risk of moral hazard i.e. governments' capitalizing on an insurance mechanism to create excessive debts and deficits. Such a political union will be necessary to sustain the monetary union in the long run. As long as the member states are unwilling to move to that direction, the system remains fragile (De Grauwe, 1992). In order to get a better understanding of the lack of an automatic mechanism of this kind and the impracticability of the political union with the current state of affairs, the route to the Monetary Union devised in Maastricht has to be examined and an assessment of the Treaty has to be given.

\section{The Route to EMU according to the Maastricht Approach}

The examination addresses the issues as follows in nutshell: fiscal federalism, convergence, currency stabilization and some aspects of the operation of the European Central Bank (ECB).

\subsection{Fiscal federalism}

Literature discussing fiscal federalism defines it as assignation of expenditure and tax/transfer competences to different government levels (Oates, 1999). To apply it to Monetary Union the theory should deal with income redistribution and stabilization within a region, and dynamic issues such as disparities and asymmetries while the EMU states move to the direction of a federalist structure. It does not. The principle of subsidiarity, however, is an important implication for the Union according to which a higher government level should assume responsibilities that a lower level cannot take care of effectively (The Maastricht Treaty, Article 3b). It implies preferring national autonomy in regulation i.e. coordination to harmonization or centralization generating a tension between them. Only if coordination attempts have failed between member countries is harmonization, as a last resort, to turn to. For the implementation of the subsidiary principle in practice the argument can be found in national differences in tastes and needs, better democratic control of public services at a national level and increased competition and innovation between national authorities in supplying public goods and services in a decentralized way (Courchene et al., 1993). Since the degree of free mobility of labour is insufficient despite the implementation of the single market due to cultural and linguistic differences the third argument arises doubts. Literature identifies cases for assigning competences other than principle of subsidiarity such as spillover effects of national policies, economies of scale, national policies are indivisible, the pursuit of homogeneity or fairness (Plender, 1991). The homogeneity argument, which is referred to as national standards in Canada, raised debates in Europe on European Commission's initiating directives on areas it had no competence instead of following the subsidiarity principle. It is the field of disparities of the regions where the principle of subsidiarity could trouble the Monetary Union. The economic principle of fiscal federalism, the resource flow principle, justifies the political tensions stemming from gaining and losing in the structure. Mature federations can be characterized by a significant degree of expenditure and revenue centralization. In a federalist structure regional disparities may be expected to diminish through the resources' flowing from the wealthier to the poorer members. The level of acceptance of resource flow in general and in regional income redistribution might be much higher in federations such as the USA, Australia or Canada owing to linguistic and cultural similarities and factor mobility in comparison with the European Union. The degree of political homogeneity cannot be neglected even if economic benefits in terms of an increase in overall welfare have been obviously shown. Courchene et al (1993) revealed an inverse relationship between the public finance autonomy of a member state and interregional redistribution due to the fact that interregional redistribution capacity depends on the size of the federal budget relative to the budget of member states (other things being equal). A federation creates recipients and providers (winners and loosers respectively) referred to as the issue of fairness. In the European Union budgetary fairness i.e. beliefs concerning the procedural and distributive justice of the supranational budgetary process has always been a major issue in terms of net contribution to the EU. I assume fairness may affect the commitment of the state depending not only on the fairness of the budgeting process rather on the fairness of the budget target assigned.

\subsection{Convergence under Maastricht}

The Maastricht convergence criteria were set for individual countries with a double purpose in terms of moving to stage 3 of the Delors plan. Economies were bound to maintain a convergent pathway with respect of both monetary and fiscal policies. The criteria indicated national governments' participating in end games, facilitated a smooth transition period and were agreeable in complementing the stability of exchange rates 
foreseen for the EMS. To the date the convergence criteria were specified practically no member state was eligible in terms of meeting the criteria [see De Grauwe and Gros (1991)], even in April 1995 out of 12 member states only Ireland and Luxembourg met all four criteria, while Greece, Italy, Portugal and Spain met none of them (EMI, 1996). The Maastricht Treaty (1992) Article 109j states that the Commission and the EMI shall report to the Council on the fulfillment of the obligations of the Member States regarding the achievement of economic and monetary union and on the degree of convergence with respect of price stability, the government financial position, currency stabilization and the durability of convergence reflected in the long-term interest rate levels. According to Article 109 indent 3 Member States should observe "the normal fluctuation margins provided for by the Exchange Rate Mechanism of the European Monetary System, for at least two years without devaluing against the currency of any other Member State". "Normal fluctuation margins" meant $+/-2.25$ percent at the time that the Treaty was signed. Following the currency crisis in the ERM in 1993 the fluctuation margins for all the currencies in the system were widened to 15 percent on each side of the central parity. The increased width of the fluctuation bands facilitated respecting the limits as well as meeting the Treaty's additional requirement that the member state has not devalued its currency's bilateral central rate against any other member state currency "on its own initiative for the same period." To assess the degree of European monetary integration it is necessary to define the term "convergence". Collignon (1994) suggests measuring the system in terms of the Maastricht convergence criteria themselves as they qualify the state entering the monetary union termed as the political approach while defining convergence in terms of "purchasing power theory" (PPP) referred to as the economic approach.(Leydessdorff, 1999). Measured by Maastricht standards the system seems to have converged in terms of inflation rates, interest rates, fiscal deficits and nominal exchange rates. This monetary integration process ended up in adopting the single currency, the euro, implying a system of fixed nominal exchange rates. On the other hand based on information theory (Shannon, 1948) Leydesdorff concludes that defining convergence as contributions to system formation countries that introduced a floating or strongly fluctuating nominal exchange rate regime following the currency crisis in 1992-1993 failed to converge in nominal terms, but performed better in terms of real convergence. They contributed to the formation of a system at the economic level more than those with monetary regimes linked strongly to that of Germany. Consequently monetary integration does not obviously include economic integration. According to the theory of optimum currency areas [(OCA), Mundell, 1961)] sufficient real wage flexibility and labour mobility can compensate for real divergences. The lack of those in Europe makes it less likely that the requirements of a sound monetary union can be met. In addition market efficiency with prices fully reflecting available information has not been constituted by the European Union, which also suggests that monetary integration does not imply economic integration. Maastricht has brought the loss of two economic policy levers, monetary and exchange rate policies, and has left two other, the national fiscal policies and the EU budget itself. It means national governments are restrained in reacting to asymmetric shocks, the outcome of which depends to a great extent on the relative phasing of business cycles between each member state and on the ability that cycles can be responded through the EU budget. Since monetary sovereignty and exchange rate tool are no longer accessible fiscal latitude is needed for the members to treat shocks, particularly in an environment where labour migration has failed to function as a valve for dealing with asymmetric shocks.

\subsection{Currency stabilization and using the ERM to achieve EMU}

Article $109 \mathrm{j}$ indent 3 about the normal fluctuation margins of $+/-2.25$ percent implied by the Treaty at the time when it was signed served the objective of ensuring that the currency of member state joining EMU was at a sustainable level for a longer period of time. Fiscal, monetary and exchange rate criteria seem to have been incongruous with the objectives of EMU taking all aspects into account. On occurrence of transitory shocks the expected time preceding entry into stage 3 could lengthen and foreign exchange markets became turbulent. The response of central banks to the turbulences exacerbated the situation in economic criteria terms and affected expectations. Due to the narrow space for manoeuvring in the foreign exchange market transitory shocks could permanently modify expectations. The room for manoeuvring was further limited proportionally by the weight of the currency in the ECU basket given the ERM operated around the ECU, a weighted basket of the EMS currencies. The adjustable peg exchange rate system which could work effectively in reducing volatility may not have been the right way in moving towards EMU on a pathway set by criteria.

\subsection{Some aspects of the operation of the ECB}

Central Bank independence is a priority for Maastricht. The Bundesbank in Frankfurt became the de facto central bank of Europe and by pegging their currencies to the Deutsche mark EMS member states had to follow the German monetary policy in which they had no formal say. Independence enabled the Bank to maintain a strong DM and it consistently refused to loosen its monetary policy to ease exchange rate pressure on its partners. The Germans argued that the independent ECB could not operate in a vacuum meaning that a central bank had to have a governmental framework to operate in. The lack of an equivalent institution in fiscal matters results in a lack of proper interaction between monetary and fiscal policy on European level. The lack of synchronized business cycles has been 
a problem since there is only one central bank with one monetary policy to fit all the members and has generally followed a monetary policy that makes sense for Germany.

\section{Summary and Conclusions}

The process of the European economic integration starting with the establishment of the European Economic Community (EC) in 1958 can be considered successful. Between 1958 and 1972 the intra EC trade increased from approximately $30 \%$ to over $50 \%$ of the total international trade of the six member countries, the EC share in the world trade increased from $21.9 \%$ to $29.8 \%$, while the trade share of the USA dropped from $16.3 \%$ to $11.7 \%$ (Salvatore, 2001). After a period of a stagnating intra-EC trade in the total world trade and a decreasing intra- EC trade as a percent to EC output in the mid 80s the Treaty of Rome was amended with the Single European Act (SEA) in 1986, which gave a new moving force to the European integration process. By the beginning of 1993 a European Single Market had evolved with all remaining barriers removed to the free flow of goods, services and resources among members. SEA implied unifying national production standards, abolishing differences in all taxes and unifying the European financial markets through slackening national capital movements' control. The Maastricht criteria on monetary union include low inflation and interest rates, exchange rate stability, public deficits below 3 percent and government debt no higher than 60 percent of gross domestic product. Since only Germany, France and Luxembourg were to fulfill the criteria by the end of 1996 the chance for a fast track monetary union was abandoned and the launch date was set to 1999.

In contrast with the successes of the Customs Union and the Single Market the history of creating European Monetary Union cannot be considered that successful since attempts had failed. The Werner Plan approved in 1971 proposed the irrevocable fixing of exchange rates and the adoption of a single currency until 1980. The plan failed due to the pressures of the USA and the crisis of 1971-73. The strategy of a monetary union was sustained by the EC member states. Progress was made in stabilizing exchange rate relations between their currencies on the basis of the Basel agreement "snake in the tunnel", and in 1972 the fluctuation margin among EC currencies was fixed at 2.25\%. The plan failed when participating currencies (British, French, Italian and Irish) had left the system. Despite these failures the European Monetary System (EMS) was established in 1979. This paper has shown how the EMS and its Exchange Rate Mechanism (ERM) worked, how the "new ERM" evolved and how its crisis emerged. The question arises whether the ERM crisis could have been averted. I conclude that without fundamental changes the crisis in 1993 could not have been avoided since the new ERM was intrinsically susceptible to shocks. The main argument for all monetary union plans was to curb inflation, the big enemy. In this respect the EMS functioned well through providing credibility and discipline to countries with high inflation as paper presented. However, disinflation argument is not justified by the fact that Italian, Spanish, Portuguese and UK inflation continued to fall after they had left the ERM in September 1992. The lessons from the past might help to find the way ahead. Why not drop the obsession on price stability for instance and let inflation go as a possible way out now?

The EMS, however, should have laid the groundwork for monetary union in the $21^{\text {st }}$ century. Actually it could not. The only way out of the vicious circle that evolved and resulted in the crisis of the EMS was the way out of ERM. The ERM crisis in August 1993 led to adopting new large fluctuation margins (+/- 15\%) of participating currencies. The route to monetary union was envisaged in the Maastricht Treaty as a time-specified, gradualist approach. Coupling demanding economic convergence criteria with a rigid timetable for fulfilling them surrounded by a chaotic environment of divided institutional responsibility among the European Monetary Institute (EMI) and national monetary authorities was a big structural flaw in the EMS. Consequently fundamentally sound currencies came under attack before and after the French referendum on the Treaty. As for currency stabilization, within the Maastricht formula a transitory shock that may lengthen the period of time expected before entry into stage 3 of EMU could cause turbulences in the foreign exchange markets. Due to the economic criteria central bank response such as increasing interest rates might only worsen the situation causing that expectations could be affected permanently. On the other hand the use of the ERM of the EMS, an adjustable peg exchange rate regime effectively used as an independent mechanism to reduce volatility to attain Monetary Union is incompatible with a criteria dependent dynamic process.

This paper offers an approach of examining the route to EMU to reveal the implications that the monetary union still has to bear. Facing the past may help design the future. The mistakes of the past and measures taken hastily under pressure just to avoid an even bigger trouble can hardly bring a sustainable settlement. To be concrete the problems and the economic and political tensions within the EMS made it intrinsically susceptible to shocks. I cannot say that the turbulence within the ERM was due to an unfortunate coincidence and influence of independent events although they were to blame for that. In this paper I have tried to form a consistent framework for the events and other factors and destabilizing elements that contributed to the crisis of the ERM and impacted the pathway to EMU. The monetary integration process which was dramatically accelerated following the EMR crisis resulted in the Maastricht approach to monetary union with all its doubts. Efforts should have been concentrated on reforming the EMS rather than moving fast to monetary union.

I do not say that the crisis of the euro-zone was caused by the flaws of the ERM. What I say is that instead of blaming the global economic and financial crisis for the bad state of the euro-zone the groundwork should be examined thoroughly to know better how to keep the building in existence 


\section{References}

1 Artus J., Convergence- the Maastricht Approach to Economic and Monetary Union (EMU) in Europe. Journal of Asian Economics, 4(2), Autumn 377-385 (1993).

2 Buckley A., Multinational Finance. ( $4^{\text {th }}$ ed.) Financial Times Prentice Hall, London (2000).

3 Borio C., McCauley R., The Economics of Recent Bond Yield Volatility. BIS (Bank for International Settlements) Economic Papers, 45(July) (1996).

4 Brittan S., The British Debate. Cato Journal, 23(1) (2003).

5 Cadot O., Fatas A., Gee F., From Franc Faible to Franc Fort: 12 years of French Economic Policy. INSEAD Case Studies (1996).

6 Clausen V., Willms M., Lessons from German Monetary Union for European Monetary Union. Journal of International and Comparative Economics, 3(3), 195-228 (1994).

7 Collignon S., Europe's Monetary Future. Pinter, London (1994).

8 Courchene T., Goodhart C., Majocchi A., Moesen W., Prud'homme R., Schneider F., Smith S., Spahn B., Walsh C., European Economy: Stable Money-Sound Finances. 53 (1993).

9 De Grauwe P., The Liberalisation of Capital Movements and the EMS. in 'Prospects for the European Monetary System' (ed.: Ferri P.) MacMillan, Basingstoke, UK (1990).

10 De Grauwe P., Gros D., Convergence and Divergence in the Community's Economy on the Eve of Economic and Monetary Union. in 'Setting European Community Priorities 1991-92' (ed.: Ludlow P.) 9-37, Centre for Economic Policy Studies, Brussels, Belgium (1991).

11 De Grauwe P., The Economics of Monetary Integration. (1 $1^{\text {st }} \mathrm{ed}$.), Oxford University Press (1992).

12 De Grauwe P., Towards EMU without the EMS. Economic Policy, 9(18), 147-185 (1994).

13 De Grauwe P., Alternative Strategies towards Monetary Union. European Economic Review, 39(3-4), 483-491 (1995). DOI: 10.1016/0014-2921(94)00054-4

14 De Grauwe P., Moesen W., Common Euro Bonds: Necessary, Wise or to be Avoided? Itereconomics, 44(3), 132-141 (2009). DOI: $10.1007 / \mathrm{s} 10272-009-0287-\mathrm{x}$

15 De Grauwe P., The Governance of a Fragile Eurozone. in 'Economic Policy, CEPS Working Documents'No. 346, (May. 2011). http://www.econ.kuleuven.be/academic/Discussion papers (2011)

16 Deutsche Bundesbank. The Crisis within the EMS and its Lessons. Deutsche Bundesbank Annual Report, 1-8 (1992).

17 Athanassiou P., Withdrawal and Expulsion from the EU and EMU: Some Reflections. ECB (European Central Bank), Legal Working Paper Series, No.10, (December 2009).

http://www.ecb.europa.eu

18 Eichengreen B., Wyplosz C., The Unstable EMS. CEPR Discussion Paper 817, Centre for Economic Policy Research, London (May 1993).

19 European Monetary Institute, European Monetary Institute: Annual Report 1995. Frankfurt, Germany (1996).

20 Fratianni M., The European Monetary System: How well has it Worked? Cato Journal, 8(2), 477-501 (1988).
21 Fratianni M., Hagen J., German Dominance in the EMS: The Empirical Evidence. Open Economies Review, 3(1), 127-128 (1992). DOI: $10.1007 / \mathrm{BF} 01886185$

22 Fuceri D., Zdzienicka A., The Consequences of Banking Crises for Public Debt. OECD Economic Department Working Papers, No. 801, 2010.

23 Giovannini A., The Transition to European Monetary Union. Essays in International Finance, 178, Princeton University, New Jersey, USA (1990).

24 Giavazzi F., Giovannini A., Limiting Exchange Rate Flexibility: the European monetary system. MIT Press, Cambridge, Massachusetts, USA (1989).

25 Gros D., Mayer T., Disciplinary Measures. The Economist, February 18 (2010).

26 Hayek F. A., The Future Monetary Unit of Value. in 'Money in Crisis' (ed.: Siegel B. N.) 323-336 (1984).

27 Leydesdorff L., Oomes N. A., Is the European Monetary System Converging to Integration? Social Science Information, 38, 57-86 (1999). DOI: $10.1177 / 053901899038001003$

28 Melitz J., Monetary Discipline and Cooperation in the European Monetary System: a synthesis. in 'The European Monetary System' (eds.: Giavazzi F., Micossi S., Miller M.) Cambridge University Press, 51-84 (1988). Chapter DOI: 10.1017/CBO9780511628535.005

29 Melitz J., Zumer F., Interregional and International Risk Sharing and Lessons for the EMU. Carnegie- Rochester Conference Series on Public Policy, 51 149-188 (1999). DOI: $10.1016 / \mathrm{S} 0167-2231(00) 00008-7$

30 Mundell R., A Theory of Optimum Currency Areas. The American Economic Review, 51(4), 657-665 (1961).

31 Mundell R., The European Monetary System 50 Years after Bretton Woods: A Comparison Between Two Systems. Project Europe 1985-95, (the tenth edition of the "Incontri di Rocca Salimbeni" meetings) Siena, Italy (1994).

32 Oates W., An Assay on Fiscal Federalism. Journal of Economic Literature, 37(3), 1120-1149 (1999). DOI: $10.1257 /$ jel.37.3.1120

33 Pinder J., European Community: The Building of a Union. Oxford University Press, Oxford, New York, USA (1991).

34 Salvatore D., International Economics. (7 $7^{\text {th }}$ ed.) John Wiley and Sons, New York, USA (2001).

35 Shannon Claude E., A Mathematical Theory of Communication. The Bell System Technical Journal, 27, 379-423 (1948).

36 Siegel B. N., Money in Crisis. Ballinger Publishing Company, Cambridge Massachusetts, USA (1984).

37 Tsoukalis L., The Politics and Economics of European Monetary Integration. George Allen and Unwin, London, UK (1977). 